\title{
VÁLTOZÓ INERCIÁJÚ KONZOLTARTÓK CSILLAPÍTATLAN SZABADREZGÉSEINEK VIZSGÁLATA
}

\author{
DR. HUSZÁR ZSOLT* \\ okl. építőmérnök, mérnök-matematikai szakmérnök, \\ tudományos mts.
}

\section{BEVEZETÉS}

A közelmúltban egy fontos ipari létesítmény szellőző kéményének vizsgálatában vettem részt. A kémény keresztmetszeti méretei fölfelé haladva fokozatosan csökkentek. A kéményt vizsgáltuk földrengés-teherre és a szélteher dinamikus hatására. A széliránnyal párhuzamos síkban dinamikus hatást kelthet az ingadozó szélsebesség és emellett magas, karcsú építmények esetében a Kármán-féle örvényleválás keresztirányú gerjesztést is okozhat. Mindez szükségessé tette a változó keresztmetszetű konzoltartó dinamikai jellemzőinek meghatározását.

A cikkben a változó keresztmetszetű konzoltartók sajátfrekvenciáinak és rezgési alakjainak számítására szolgáló eljárást mutatok be. Az általam kidolgozott kontinuum módszer a Rayleigh-hányados szélsőérték tulajdonságára épül és felhasználja az állandó keresztmetszetủ konzolrúd dinamikai megoldását. Előnye, hogy adatbeviteli igénye jóval kisebb, mint egy részletes végeselemes modellé. Az ismertetésre kerülő eljárás a mérnöki gyakorlatban előforduló más, konzoltartóval modellezhető szerkezetre - pl. adótorony - is alkalmazható.
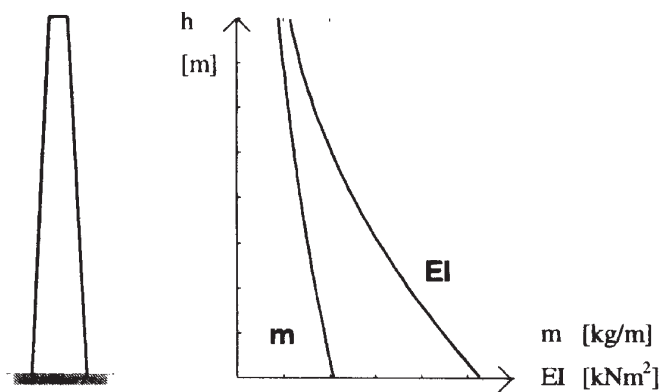

1. ábra. Változó merevségű konzolrúd fajlagos tömege és hajlítómerevsége a magasság mentén

* MTA Vasbeton Kutatócsoport, BME Hidak és Szerkezetek Tanszéke. 1111 Budapest, Bertalan Lajos u. 2. Tel.: 463-1743, Fax: 463-1784. 
Az 1. ábrán egy változó keresztmetszetủ konzolrúd, valamint a rezgési jellemzőit meghatározó fajlagos tömegének és hajlítómerevségének magasság szerinti változása látható alakhelyes grafikonban. A fajlagos tömeg közvetlenül a keresztmetszeti területtel, a hajlítómerevség pedig a keresztmetszet tehetetlenségi nyomatékával arányos. Az ábrából kitúnik, hogy felfelé haladva a hajlítómerevség gyorsabban csökken, mint a fajlagos tömeg.

\section{A SZÁMÍTÁSI MÓDSZER ISMERTETÉSE}

A szabad, csillapítatlan hajlítórezgést végző, változó keresztmetszetủ konzolrúd dinamikai jellemzőinek meghatározásához kontinuum módszer szerint előállítottam az állandó keresztmetszetủ konzolrúd rezgési alakját, majd ennek fokozatos módosításával számítottam a változó keresztmetszetủ rúd sajátfrekvenciáját a Rayleigh-hányados szélsőérték tulajdonságának felhasználásával.

A levezetésekben a következő feltevéseket, ill. megszorításokat alkalmaztam:

- nem számolok az elfordulási tehetetlenséggel,

- a nyírási deformációkat elhanyagolom,

- a statikus normálerőket ugyancsak elhanyagolom,

- a konzolrúd tőkeresztmetszete mereven befogott,

- a keresztmetszeti jellemzők változását folytonos függvények írják le.

Magas, toronyszerü szerkezetek rezgési jellemzőit a nyírási deformációk kevéssé befolyásolják. A statikus normálerők hatása szintén nem jelentős, ha az önsúly okozta normálerő távol esik a kritikus erő szintjétől. Az eljárás mindemellett a fenti megszorítások elhagyásának eseteire is kiterjeszthető.

\subsection{AZ ÁLLANDÓ KERESZTMETSZETŰ KONZOLRÚD MEGOLDÁSA}

Az állandó keresztmetszetủ gerenda csillapítatlan hajlítórezgéseit az alábbi állandó együtthatós homogén, parciális differenciálegyenlet írja le [1], [2]:

$$
E I \frac{\partial^{4} w}{\partial x^{4}}+\rho A \frac{\partial^{2} w}{\partial t^{2}}=0
$$

ahol: $w$ : a rúd keresztmetszeteinek a rúd tengelyére merőleges eltolódása a rezgés síkjában

$A$ : a rúdszelvény keresztmetszeti területe 
I: a rúdszelvény hajlítási inerciája a rezgés síkjára meröleges tengelyre

$\rho: \quad$ a rúd anyagának testsűrüsége

$E: \quad$ a rúd anyagának rugalmassági modulusa

A konzolrúd esetén a differenciálegyenlethez az alábbi geometriai és statikai peremfeltételek tartoznak:

$$
\begin{array}{ll}
x=0 \text { helyen: } & w(0, t)=0 \\
& w^{\prime}(0, t)=0 \\
& M=E l w^{\prime \prime}(\ell, t)=0 \\
x=l \text { helyen: } \quad & Q=E l w^{\prime \prime \prime}(\ell, t)=0
\end{array}
$$

ahol: $\quad Q: \quad$ a rúdban ébredő nyíróerő a hajlítórezgés síkjában

$M: \quad$ a rúdban ébredő nyomaték a hajlítórezgés síkjában

$l: \quad$ rúdhossz

Az (1) differenciálegyenlet a változók szétválasztásával oldható meg. Az ismeretlen $w(x, t)$ eltolódás-függvényt vegyük fel egy $x$-től és egy $t$-től függő függvény szorzataként:

$$
w(x, t)=y(x) T(t)
$$

Az (1) egyenlet a (3) behelyettesítésével két közönséges differenciálegyenletre válik szét. A sajátfrekvenciákat és a rezgési alakokat a helykoordinátát tartalmazó (4) egyenlet megoldásával kapjuk:

$$
E I y^{I V}-\omega^{2} \rho A y=0
$$

ahol: $\omega$ : a szabadrezgés körfrekvenciája.

A rezgési függvényt $y=e^{\alpha x}$ alakban keresve, az alábbi karakterisztikus egyenletet kapjuk:

$$
\alpha^{4}-\omega^{2} \frac{\rho A}{E I}=0
$$

a karakterisztikus egyenlet megoldása:

$$
\alpha_{1,2}= \pm \lambda_{1} \quad \alpha_{3,4}= \pm \lambda_{2} i \quad \text { ahol: } \lambda=\sqrt[4]{\omega^{2} \frac{\rho A}{E I}}
$$


Ebből az állandó keresztmetszetú konzol rezgésalakja [3], [4]:

$$
\zeta_{0}(x)=c_{1} e^{\lambda x}+c_{2} e^{-\lambda x}+c_{3} \sin \lambda x+c_{4} \cos \lambda x
$$

A $\lambda$ argumentumban foglalt $\omega$ körfrekvencia és a $c_{i}$ együtthatók a (2) peremfeltételekből határozhatók meg. A négy peremfeltétel egy négy egyenletből álló egyenletrendszert képvisel. Mátrixos írásmódban:

$$
[A(\lambda(\omega))]\{c\}=\{0\}
$$

ahol: $[A]$ : $4 * 4$-es mátrix, melynek elemei a (6) egyenletben szereplő 4 alapfüggvényből a 4 peremfeltétel szerint képzett kifejezések

$\{c\}:$ az ismeretlen $c_{i}$ együtthatók 4 elemü vektora

A sajátfrekvenciákat és a sajátrezgési alakokat a (7) egyenlet nemtriviális megoldásaiként kapjuk. Ilyen nemtriviális megoldást az alábbi összefüggés szolgáltat:

$$
\operatorname{det}[A(\omega)]=0
$$

Azok az $\omega$ értékek melyek az $[A]$ mátrix determinánsát zérussá teszik, a rezgés sajátfrekvenciái. $\mathrm{Az} \eta=\operatorname{det}[A(\omega)]$ függvény (2. ábra) zérushelyeit valamely iterációs eljárás segítségével határozhatjuk meg [5].

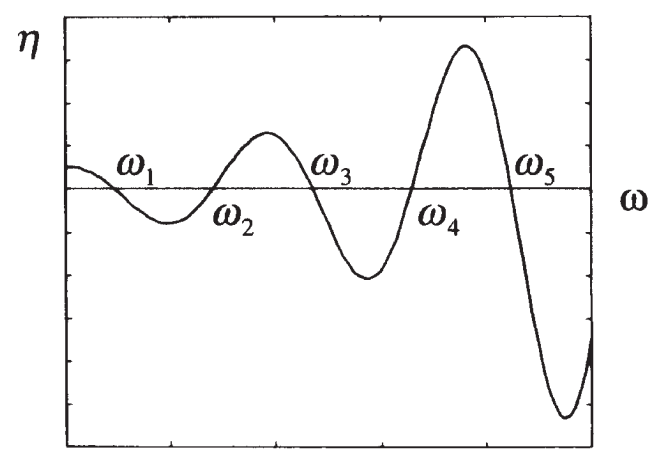

2. ábra. $\mathrm{Az} \eta=\operatorname{det}[A(\omega)]$ függvény

Ezután a tetôponti eltolódást egységnek választva és az (7) egyenletrendszer egyik egyenletét ezzel a feltétellel helyettesítve, meghatározhatók a $c_{i}$ együtthatók is, melynek eredményeként a tetőponti eltolódásra normált rezgési alakokat kapjuk. 


\subsection{A RAYLEIGH-HÁNYADOS REZGŐ GERENDÁKRA VONATKOZÓ ALAKJA ÉS SZÉLSŐÉRTÉK TULAJDONSÁGA}

A Rayleigh-hányados rezgő gerendákra vonatkozó alakja - valamely $y(x)$ feltételezett rezgési alakból kiindulva - a körfrekvenciára ad becslést a (9) összefüggés szerint:

$$
\omega^{2}=\frac{\int_{0}^{l} E I\left[y^{\prime \prime}(x)\right]^{2} d x}{\int_{0}^{l} \rho A[y(x)]^{2} d x}
$$

A (9) kifejezés abszolút minimumát - a rezgési probléma, mint általánosított sajátérték-feladat legkisebb sajátértékét [6] - vagyis a legkisebb körfrekvenciát akkor kapjuk, ha az $y(x)$ helyére az első módusznak megfelelő alakfüggvényt helyettesítjük. A rezgési alakok ortogonalitása miatt a további sajátfrekvenciák lokális minimumokat képviselnek.

A Rayleigh-hányados rezgő gerendákra vonatkozó alakjának szemléletes mechanikai interpretációja adható az alábbi módon. Tekintsük valamelyik, pl. az első módusza szerint szabadon rezgő konzolrudat. Mint ismeretes, a szabad rezgést végző rendszer mechanikai energiája állandó, mivel éppen a szabad rezgőmozgás következtében a környezetétől nem vesz fel és a környezetének nem ad le energiát. Vizsgáljuk a rezgés egy periódusát (3. ábra).

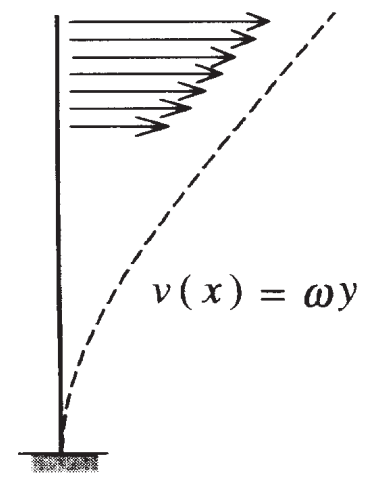

a) Sebesség eloszlás a $t=0$ időpontban

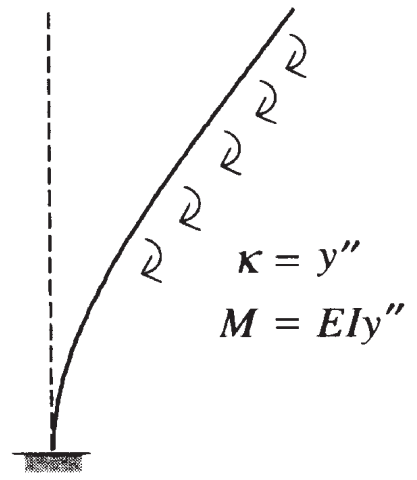

b) Görbület és nyomaték a $t=\mathrm{T} / 4$ időpontban

3. ábra. A Rayleigh-hányados mechanikai interpretációja 
A rúd pontjai azonos fázisban mozognak és a $t=0$ időpontban egyszerre haladnak át a nyugalmi helyzeten (3.a ábra). A sebességeloszlás az amplitúdóval konform. Ez jelen esetben az $y$ függvénnyel jelölt rezgési alak. A harmonikus rezgőmozgás alapösszefüggései szerint kapjuk a $v(x)$ sebességeloszlást. A rúd teljes mozgási energiája:

$$
E_{k i n}=\frac{1}{2} \int_{0}^{l} m v^{2}(x) d x=\frac{1}{2} \int_{0}^{l} \rho A(\omega y)^{2} d x
$$

A rúd pontjai a $t=\mathrm{T} / 4$ időpontban elérik a szélső helyzetüket (3.b ábra). A rúd mozgási energiája teljes egészében rugalmas alakváltozási energiává alakul át. Az $y$ rezgési alakfüggvényből az elemi szilárdságtan összefüggései segítségével kifejezhetjük a $\kappa(x)$ görbületet és az $M(x)$ nyomatékot. Ebből a rúdban felhalmozódó összes potenciális energia a (11) összefüggés szerinti:

$$
E_{p o t}=\frac{1}{2} \int_{0}^{l} M(x) \kappa(x) d x=\frac{1}{2} \int_{0}^{l} E I\left[y^{\prime \prime}(x)\right]^{2} d x
$$

A kétféle energiát egyenlővé téve, majd $\omega^{2}$-et kifejezve, megkapjuk a Rayleighhányados ismert alakját (9):

$$
E_{k i n}=E_{p o t} \Rightarrow \omega^{2}=\frac{\int_{0}^{l} E I\left[y^{\prime \prime}(x)\right]^{2} d x}{\int_{0}^{l} \rho A[y(x)]^{2} d x}
$$

A kifejezett $\omega^{2}$ a (9) függvény stacionárius pontja (abszolút, vagy lokális minimum), mert az $y(x)$ függvény az (1) differenciálegyenletet kielégítő rezgési alak.

Rayleigh-módszerével az állandó keresztmetszetű rudak sajátfrekvenciáira egyszerű közelítést ad az $y(x) \equiv x^{3}$ rezgési alak feltételezése. Tekintve, hogy e harmadfokú parabolával a rúd $x=l$ szabad végén a (2.b) statikai peremfeltételek nem elégíthetők ki, a (9) hányados várhatóan nem ad túl jó becslést.

\subsection{A VÁLTOZÓ KERESZTMETSZETÜ KONZOLRÚD MEGOLDÁSA}

A Rayleigh-módszer hatékony alkalmazásának kulcsa a tényleges rezgési alakot minél jobban megközelítő $y(x)$ függvény felvétele. Az általam kidolgozott eljárás éppen ezt célozza meg. 
A keresztmetszeti jellemzőknek a rúd hossza mentén való változását az alábbi függvényekkel írhatjuk fel:

$$
A(x)=A_{0} f(x) \quad I(x)=I_{0} g(x)
$$

ahol: $A_{0}$, ill. $I_{0}$ a tőkeresztmetszet keresztmetszeti területe, ill. inerciája $f(x)$, ill. $g(x)$ a terület, ill. az inercia változását leíró folytonos függvény $x=0$ helyen $f(0)=1$, ill. $g(0)=1$, és a függvények monoton csökkenőek.

A fenti $A(x)$ és $I(x)$ függvényeket (4) egyenletbe helyettesítve a (13) változó együtthatós differenciálegyenletet kapjuk, mely általában nem oldható meg zárt alakban:

$$
E I_{0} g(x) y^{I V}-\omega^{2} \rho A_{0} f(x) y=0
$$

A keresztmetszeti jellemzők (12) szerinti változását figyelembe véve a (9) kifejezés az alábbi alakot ölti:

$$
\omega^{2}=\frac{E I_{0}}{\rho A_{0}} \frac{\int_{0}^{l} g(x)\left[y^{\prime \prime}(x)\right]^{2} d x}{\int_{0}^{l} f(x)[y(x)]^{2} d x}
$$

Az állandó keresztmetszetű rúd (6) szerinti rezgésalakját a (14) Rayleigh-hányadosba behelyettesítve $\omega^{2}$-re már természetesen nem kapunk minimumot, hiszen a (6) függvény nem elégíti ki a (13) változó együtthatós differenciálegyenletet.

Az általam kidolgozott módszer lényege, hogy a (6) függvényből kiindulva, annak módosításával határozom meg a változó keresztmetszetủ rúd rezgési alakját. Ebből a célból a keresett $y=\zeta(x)$ függvényt állítsuk elő az állandó keresztmetszetü rúd $\zeta_{0}(x)$ rezgésalakjának és egy $n+1$ ismeretlen együtthatót tartalmazó $n$-ed fokú polinom szorzataként:

$$
\begin{aligned}
\zeta(x) & =\left(c_{1} e^{\lambda x}+c_{2} e^{-\lambda x}+c_{3} \sin \lambda x+c_{4} \cos \lambda x\right)\left(a_{0}+a_{1} x+a_{2} x^{2}+\ldots\right)= \\
& =\varsigma_{0}(x) \sum_{n=0}^{N} a_{n} x^{n}=\varsigma_{0}(x) u(x)
\end{aligned}
$$

A rezgési alak tartalmaz egy - a normáláshoz felhasználható - szabad paramétert, válasszuk például az $a_{0}$ tényezőt vagyis az $x^{0}$ tag együtthatóját 1-nek. Így 
összesen $n$ ismeretlen együttható áll rendelkezésünkre a legjobban közelítő $y=\zeta(x)$ alakfüggvény beállításához.

A (15) rezgési alak felhasználásával a keresett körfrekvencia legjobb közelítését úgy kapjuk, hogy a Rayleigh-hányados szélső értékét képezzük az $a_{1}, \ldots, a_{N}$ függvényében:

$$
\omega^{2}\left(a_{1}, \ldots, a_{N}\right)=\min !
$$

A (16) feltétel egyúttal a rezgésalak (15) összefüggés szerinti legjobb közelítését is jelenti az $u(x)$ polinomok $N$ dimenziós alterében.

A minimumfeltétel kifejezhető a Rayleigh-hányados $N$ számú parciális deriváltjával:

$$
\frac{\partial\left(\omega^{2}\right)}{\partial a_{i}}=\frac{E I_{0}}{\rho A_{0}}\left(\frac{\int_{0}^{l} g(x)\left\{\left[\varsigma_{0}(x) u\left(a_{1}, x\right)\right]^{\prime \prime}\right\}^{2} d x}{\int_{0}^{l} f(x)\left[\varsigma_{0}(x) u\left(a_{1}, x\right)\right]^{2} d x}\right)_{, a_{i}}=0
$$

A (17) parciális deriváltakban a szorzatfüggvény, valamint a hányadosfüggvény differenciálási szabályát alkalmazva elóállíthatjuk a stacionaritási feltételt kifejező $i$ db skalár egyenletet. A deriváltak explicit felírása az $a_{i}$ tényezőkre nézve nemlineáris egyenletrendszert eredményez. A gyakorlati számításban a nemlineáris egyenletrendszer megoldása helyett célravezetőbb a Nelder-Mead-féle szimplex módszer alkalmazása [7]. Az eljárás az $\omega$ körfrekvenciára felső korlátot szolgáltat. A módosító függvény fokszámának növelésével a kapott érték a tényleges körfrekvenciát egyre jobban megközelíti. A (15) összefüggésben felhasznált egyszerü hatványfüggvény az első néhány harmónikus esetén már 3-5 $a_{i}$ paraméter alkalmazásával is jó eredményre vezet.

Magasabb harmónikusok számításánál viszont a fenti egyszerủ hatvány függvényt már nem célszerü alkalmazni. Ennek oka, hogy a (15) szorzatfüggvény csak a befogási keresztmetszet (2.a) szerinti geometriai peremfeltételeit elégíti ki maradéktalanul, a felső vég (2.b) statikai peremfeltételei a minimumkeresési eljárás során csak közelítő módon teljesülnek. A rezgési alak hullámszámának növekedésével a rúd felső végén e ki nem elégített statikai peremfeltételek egyre nagyobb pontatlanságot okoznak.

A magasabb harmónikusok számítását egy másfajta polinom típusú módosító függvény felvételével oldottam meg.

A (15) szorzatfüggvény deriváltjait elóállítva, az $x=l$ szabad vég (2.b) peremfeltételei a (18) egyenletrendszer kielégítésével teljesíthetők: 
$\left[\varsigma_{0}(x) u(x)\right]_{x=l}^{\prime \prime}=\varsigma_{0}^{\prime \prime}(\ell) u(\ell)+2 \varsigma_{0}^{\prime}(\ell) u^{\prime}(\ell)+\varsigma_{0}(\ell) u^{\prime \prime}(\ell)=0$

$\left[\varsigma_{0}(x) u(x)\right]_{x=l}^{\prime \prime \prime}=\varsigma_{0}^{\prime \prime \prime}(\ell) u(\ell)+3 \varsigma_{0}^{\prime \prime}(\ell) u^{\prime}(\ell)+3 \varsigma_{0}^{\prime}(\ell) u^{\prime \prime}(\ell)+\varsigma_{0}(\ell) u^{\prime \prime \prime}(\ell)=0$

A (18) egyenletekben a nyomaték és a nyíróerő nullértékúségét kifejező differenciálhányadosoknak csak az utolsó két-két tagja különbözik zérustól. Ennek megfelelően a (18) egyenletrendszer az alábbi módon írható:

$$
\begin{aligned}
& 2 \varsigma_{0}^{\prime}(\ell) u^{\prime}(\ell)+\varsigma_{0}(\ell) u^{\prime \prime}(\ell)=0 \\
& 3 \varsigma_{0}^{\prime}(\ell) u^{\prime \prime}(\ell)+\varsigma_{0}(\ell) u^{\prime \prime \prime}(\ell)=0
\end{aligned}
$$

A polinom típusú módosító függvényt úgy kell felvenni, hogy a (16) minimumfeltételben szereplő egyes $a_{i}$ paraméterekhez több tagból álló hatványfüggvényt rendelünk oly módon, hogy a (19) egyenletrendszert kielégítsék. Ezzel a rúdvégi statikai peremfeltételek is tagonként pontosan teljesíthetők. A (19) egyenletrendszer kielégítéséhez értelemszerűen legalább három tagból álló és két $b_{i}$ együtthatót tartalmazó polinomot kell felvenni, például a következő módon:

$u_{i}(x)=a_{i}\left(x^{i}+b_{1} x^{i+1}+b_{2} x^{i+2}\right) \quad$ és összegezve $\quad u=a_{0}+\sum_{i=1}^{N} u_{i}$

ahol ismét $a_{0}=1$.

Így a (2.b) statikai peremfeltételeket is tudjuk teljesíteni a módosító függvény $u_{i}(x)$ elemeivel.

Eszerint a változó keresztmetszetủ rúd rezgési alakfüggvénye, mely magasabb harmónikusok esetén is elegendően pontos értéket szolgáltat:

$$
\begin{aligned}
& \zeta(x)=\left(c_{1} e^{\lambda x}+c_{2} e^{-\lambda x}+c_{3} \sin \lambda x+\right. \\
& \left.+c_{4} \cos \lambda x\right)\left[1+\sum_{i=1}^{N} a_{i}\left(x^{i}+b_{1, i} x^{i+1}+b_{2, i} x^{i+2}\right)\right]=\varsigma_{0}(x) u(x)
\end{aligned}
$$

\section{MINTAPÉLDA}

Az ismertetett kontinuum módszer felhasználásával MATLAB programot készítettem, mellyel meghatároztam a már említett merev befogású, változó keresztmetszetű szellőzőkémény (4. ábra) xy síkba eső hajlítórezgésének dinamikai jel- 
lemzőit. A kémény alsó, ovális 2-2 metszetének 4,2 m hosszú egyenes szakasza lineárisan csökken zérusra a tetőpontig, miközben a falvastagság ugyancsak lineárisan 30 cm-ről 20 cm-re változik.

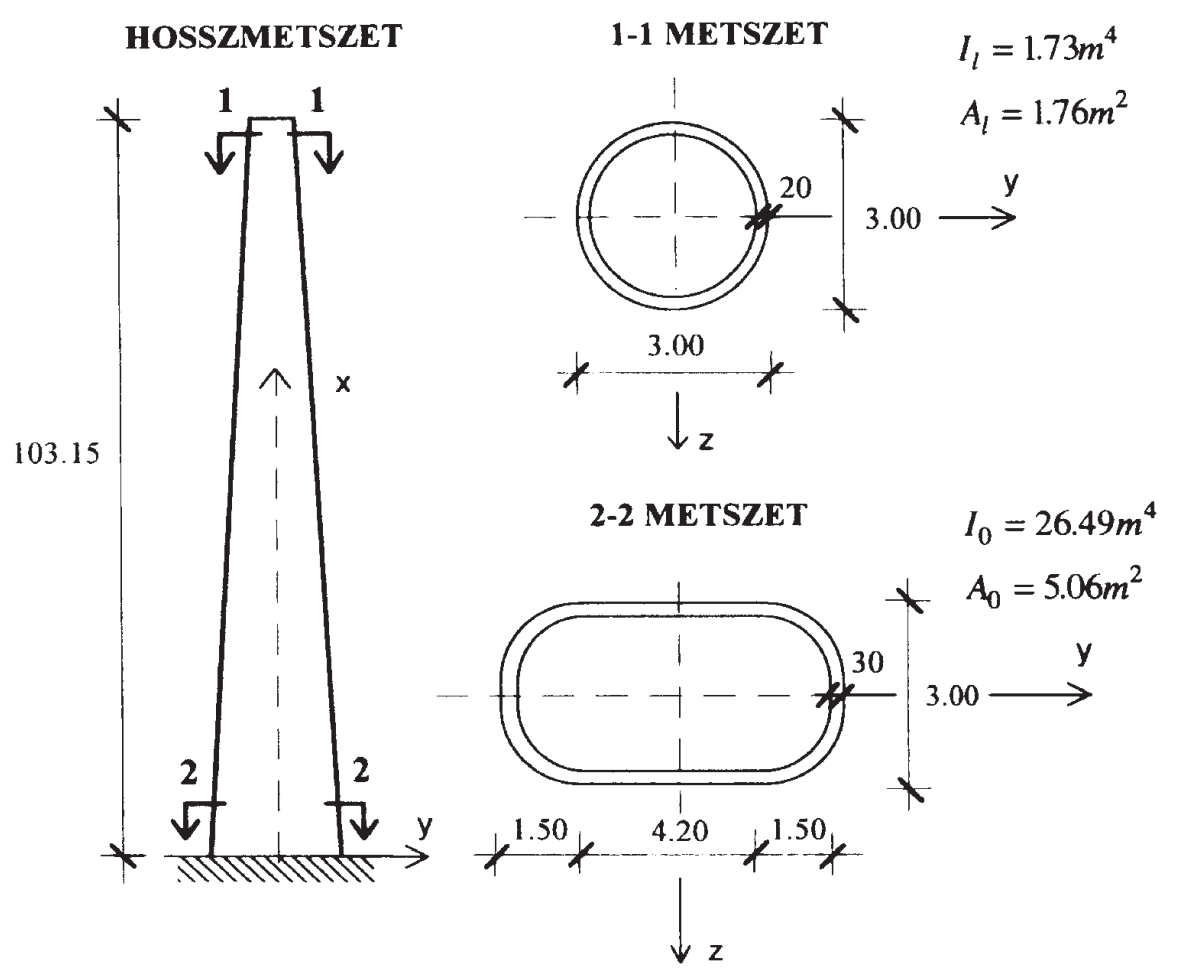

4. ábra. A vizsgált kémény jellemző keresztmetszeteivel

Első lépésben kontinuum módszerrel meghatároztam a kéményt helyettesító állandó keresztmetszetű gerenda sajátfrekvenciáit. A számítás eredményeit az 1 . táblázat tartalmazza.

1. táblázat

\begin{tabular}{lcccc}
\hline & Kereszt- & & Körfrekvencia $[\mathrm{Hz}]$, & \\
& metszet & $\omega_{1}$ & $\omega_{2}$ & $\omega_{3}$ \\
\hline Alsó & $I_{1}, A_{0}$ & 0,671 & 4,209 & 11,78 \\
Átlag & $I_{\text {átl }}, A_{\text {átl }}$ & 2,056 & 12,88 & 36,06 \\
Felső & $I_{0}, A_{1}$ & 4,442 & 27,81 & 77,87 \\
\hline
\end{tabular}


A saját körfrekvenciákra alsó és felső korlát adható a keresztmetszeti jellemzők megfelelő párosításával. Alsó korlát számításához a tetőponti kis merevséget a tőkeresztmetszet nagy fajlagos tömegével párosítjuk. Felső korlát számításához éppen fordítva, a tőkeresztmetszet nagy merevségét és a tetőpont kis fajlagos tömegét kell felhasználni. A korlátok igen tág intervallumokat adnak meg. Jó becsléshez megfelelő helyettesítő keresztmetszet felvétele szükséges, ehhez azonban semmilyen támpont sem áll rendelkezésre. Ebben a számításban az inerciát és a keresztmetszeti területet a hossz mentén vett integrál szerint átlagosítottam, de mint látni fogjuk, különösen az első sajátfrekvencia esetében nem adott jó közelítést.

A következő lépésben kontinuum módszer segítségével meghatároztam a változó keresztmetszetủ rúd sajátfrekvenciáit (2. táblázat).

\section{2. táblázat}

\begin{tabular}{lcccccc}
\hline & \multicolumn{7}{c}{ Körfrekvencia [Hz], } \\
& $\omega_{1}$ & $\omega_{2}$ & $\omega_{3}$ & $\omega_{6}$ & $\omega_{9}$ & $\omega_{12}$ \\
\hline Kontinuum & 3,110 & 13,61 & 33,87 & 159,5 & 371.2 & 674,1 \\
\hline
\end{tabular}

A táblázatból kitűnik, hogy a módszerrel nemcsak a legkisebb sajátfrekvenciát, mint a Rayleigh-hányados abszolút minimumát, hanem a magasabb sajátfrekvenciákat is, mint lokális minimumokat meg lehetett határozni. Ez annak köszönhetó, hogy az induló alakfüggvényként felhasznált állandó keresztmetszetü tartóhoz tartozó $i$. rezgésalak közelítőleg ortogonális a változó keresztmetszetủ tartó $i \neq j$ rezgésalakjaira. A Nelder-Mead-féle minimumkereső eljárás így a jó közelítésnek számító kezdő alakokból kiindulva gyorsan megtalálja a lokális minimumokat.

Az első három sajátfrekvencia számításához módosító függvényként a (15) függvényben szereplő $\sum_{n=0}^{N} a_{n} x^{n}=1+a_{1} x+a_{2} x^{2}+\ldots$ egyszerü polinom is megfelelt $N=5$ felvételével. A 6., 9., 12. sajátfrekvenciák előállításához a (21) szerinti függvényt alkalmaztam $N=1$ szabad paraméterrel.

Végül összehasonlítás céljából a változó keresztmetszetü rúd sajátfrekvencia számításait elvégeztem 103 elemre osztott végeselem modellel is, az ALGOR program felhasználásával (3. táblázat).

\section{3. táblázat}

\begin{tabular}{lccccccc}
\hline Elem- & Kereszt- & \multicolumn{7}{c}{ Körfrekvencia $[\mathrm{Hz}]$} \\
szám & metszet & $\omega_{1}$ & $\omega_{2}$ & $\omega_{3}$ & $\omega_{6}$ & $\omega_{9}$ & $\omega_{12}$ \\
\hline 103 & Alsó $I_{\mathrm{f}}, A_{\mathrm{a}}$ & 3,078 & 13,49 & 33,83 & 154,8 & 363,3 & 668,1 \\
103 & Felsó $I_{\mathrm{a}}, A_{\mathrm{f}}$ & 3,130 & 13,73 & 34,46 & 157,8 & 373,3 & 680,9 \\
\hline
\end{tabular}


A keresztmetszeti jellemzők megfelelő párosításával alsó és felső korlátot képeztem hasonlóan, mint az állandó keresztmetszetű gerenda esetében. Alsó korlát számításához a tetőponti kis merevséget a tőkeresztmetszet nagy fajlagos tömegével párosítjuk. Felső korlát számításához éppen fordítva, a tőkeresztmetszet nagy merevségét és a tetőpont kis fajlagos tömegét kell felhasználni.

A 2. és a 3. táblázatba foglalt értékeket összehasonlítva megállapítható, hogy a kontinuum módszer és a végeselemes számítás eredményei jó egyezést mutatnak.

A minimumkeresés eredményeként a sajátfrekvencia mellett a módosító polinom együtthatóit is megkapjuk. Ezek segítségével előállíthatók a változó keresztmetszetű tartó rezgésalakjai is. Az állandó és a változó keresztmetszetủ tartó hatodik rezgésalakját közös koordináta rendszerben az 5. ábrán tüntettem fel. A normált, azaz az egységnyi tetőponti eltolódást mutató görbéket összehasonlítva, a várakozásnak megfelelően megfigyelhető, hogy a változó inerciájú tartó rezgésalakjának görbülete az alsó vég közelében relatíve kisebb, mivel az inercia felfelé haladva csökken.

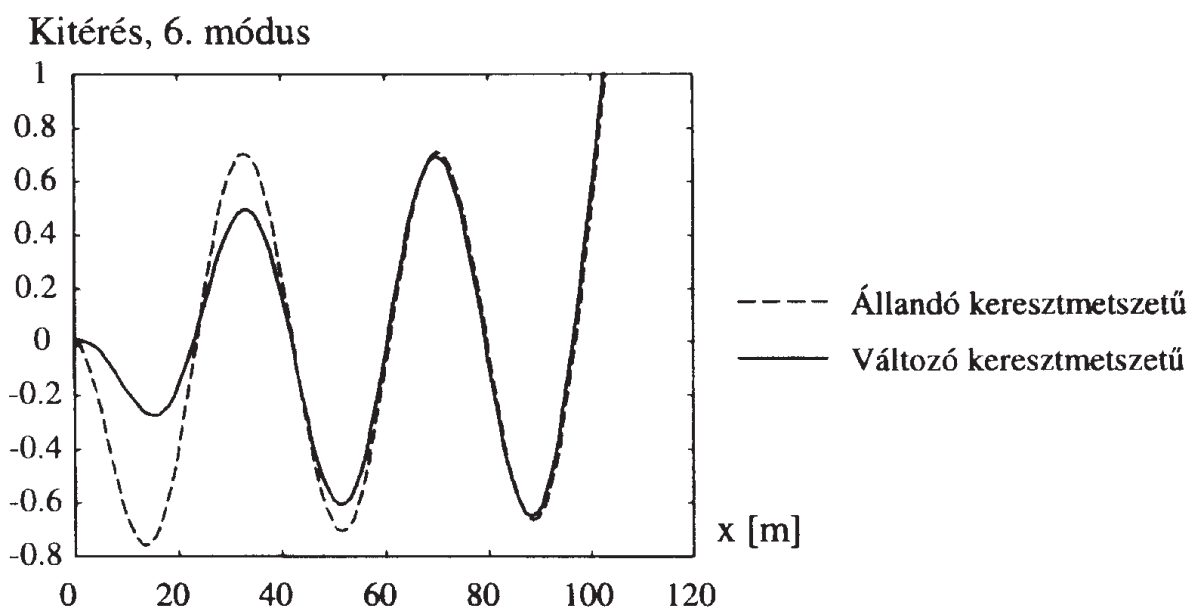

5. ábra. Az állandó és a változó inercianyomatékú konzol rezgésalakja normálással

A 6. ábrán az első sajátfrekvenciára vonatkozó minimumkeresés lépései láthatók, axonometrikusan ábrázolt koordinátarendszerben. Ennél a számításnál az ábrázolhatóság érdekében értelemszerűen másodfokú módosító függvényt vettem fel $a_{1}$ és $a_{2}$ szabad paraméterekkel.

A minimumkeresési eljárás lépéseinek szemléletes mechanikai interpretációját kaphatjuk, ha a lépésenként módosított $\zeta(x)$ függvények sorozatának egymást kö- 


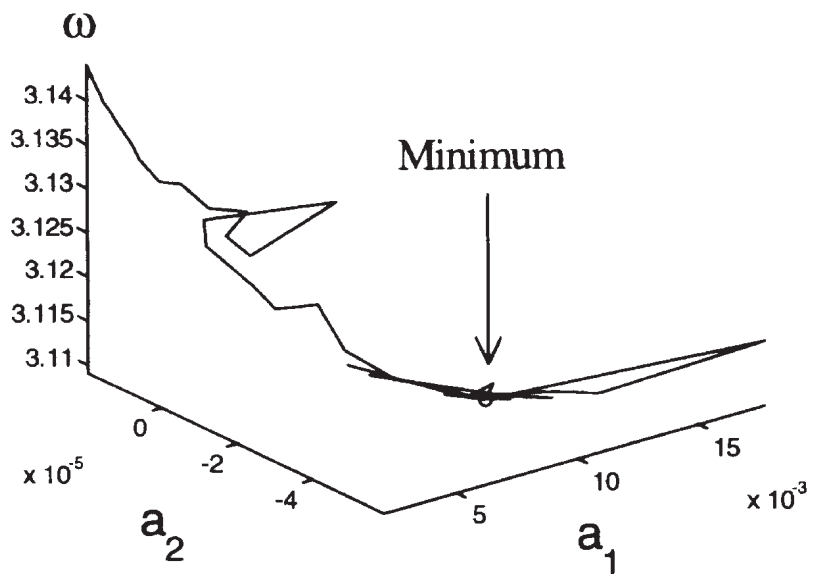

6. ábra. A Nelder-Mead-féle eljárás lépései két-paraméteres esetben

vető tagjait is rezgési alakoknak tekintjük. Ezek a függvények azonban nem lehetnek a vizsgált tartó rezgési alakjai, mert nem elégítik ki sem az (1) differenciálegyenletet, sem a (2) peremfeltételeket. Ilyen rezgési alak mégis létrehozható a vizsgált tartón, ha pótlólagos kényszereket, lehajlással és elfordulással szembeni rugalmas ágyazást alkalmazunk a mezőben és a rúd felső végén. A többlet kényszer a tartó elmerevítésével jár, ezért sajátfrekvenciái nagyobbak a vizsgált konzolénál. Az iterációs lépések így lényegében e nem kívánt többlet kényszerek fokozatos leépítését jelentik (hasonlóan a Cross-módszerhez). Ennek során a sajátfrekvencia fokozatosan csökken és közeledik a keresett elméleti értékhez. Ez az interpretáció is megmutatja, hogy az eljárás felső korlát típusú.

\section{4. ÖSSZEFOGLALÁS}

Az építőmérnöki gyakorlatban előforduló változó keresztmetszetű konzollal modellezhető szerkezetek - kémény, adótorony - dinamikai vizsgálatához többnyire vázlattervi szinten durva közelítő módszereket, a részletes számításban finomított végeselem modellt alkalmaznak. Az ilyen típusú szerkezetek hajlítórezgéseit leíró dinamikai jellemzők számítására egy gyakorlati feladat kapcsán alternatív módszerként kidolgoztam egy kontinuum eljárást.

A változó keresztmetszetű konzolrúd szabad, csillapítatlan hajlítórezgésének dinamikai jellemzőit (sajátfrekvencia, rezgési alak) az állandó keresztmetszetű konzolrúd rezgésalakjából kiindulva a keresztmetszeti jellemzők változását leíró folytonos függvényeket is tartalmazó Rayleigh-hányados szélsőérték tulajdonsá- 
gának felhasználásával határoztam meg. Ennek során a Rayleigh-hányados kifejezésében szereplő rezgési alakot fokozatosan módosítva, a sajátfrekvencia egyre jobb közelítését kaptam. Az eljárás a sajátfrekvenciákat felülről közelíti. E módszerrel nemcsak a legkisebb sajátfrekvenciát, mint a Rayleigh-hányados abszolút minimumát, hanem a magasabb sajátfrekvenciákat is, mint lokális minimumokat meg lehetett határozni. Ez annak köszönhető, hogy az induló alakfüggvényként felhasznált állandó keresztmetszetü tartóhoz tartozó $i$. rezgésalak nem tér el túlzott mértékben a változó keresztmetszetü tartó azonos sorszámú rezgésalakjától.

A bemutatott kontinuum módszer segítségével kapott eredményeket sűrü felosztású végeselem modellel előállított sajátfrekvenciákkal hasonlítottam össze. Az eredmények jó egyezést mutattak. A kontinuum módszer előnye, hogy lényegesen kisebb volumenú adatbevitelt igényel, mint a végeselem módszer.

\title{
IRODALOMJEGYZÉK
}

[1] D. D. Pfaffinger: Tragwerksdynamik. Springer Verlag, Wien-New York, 1989.

[2] R. W. Clough - J. Penzien: Dynamics of Structures. McGraw-Hill Book Company, New York, 1975.

[3] C. F. Kollbrunner - N. Hajdin: Undamped Vibration of Elastic Thin-walled Beams of Open Deformable Cross-sections. Verlag Leemann, Zürich, 1976.

[4] Zalka Károly: Dynamic Analysis of Core Supported Buildings. Building Research Establishment, 1994.

[5] G. A. Korn - T. M. Korn: Matematikai kézikönyv müszakiaknak. Müszaki Könyvkiadó, Budapest, 1975.

[6] Rózsa Pál: Lineáris algebra és alkalmazásai. Müszaki Könyvkiadó, Budapest, 1974.

[7] J. N. Reddy: Applied Functional Analysis and Variational Methods in Engineering. McGrow Hill Book Company, New York, 1986.

\section{ANALYSIS OF UNDAMPED VIBRATION OF NON-UNIFORM CANTILEVERS}

\begin{abstract}
Summary
This paper presents a continuum method which is applicable for dynamic analysis of undamped free bending vibration of structures modelled by non-uniform cantilevers, as chimneys and television towers. The essence of the procedure is that the mode shape of the non-uniform cantilever is assumed as the product of the mode shape of the uniform beam and a modifying function. Applying the extreme-value property of the Rayleigh quotient, the eigenfrequencies of the non-uniform cantilever could be obtained by gradual modification of mode shapes. By increasing the order of the modification polynome, the quotient approximates the real value of the eigenfrequency more and more. The results provided by this method are as precise as those of a detailed finite element analysis. The advantage of the continuum method is that it requires less input data than the alternative method: the finite element analysis.
\end{abstract}

Keywords: cantilever, non-uniform, Rayleigh's quotient, eigenfrequency 